Дячок Надія Валентинівна кандидат педагогічних наук, старший викладач кафедри англійської філології та перекладу, Київський університет імені Бориса Грінченка, вул. Бульварно-Кудрявська, 18/2, Київ, 04053, тел.: (044) 272-19-02, e-mail: n.diachok@kubg.edu.ua, https://orcid.org/0000-0003-1355-6801

\title{
ОСОБЛИВОСТІ ФОНЕТИЧНОЇ КОМПЕТЕНТНОСТІ У ПІДГОТОВЦІ МАЙБУТНІХ УЧИТЕЛІВ ІНОЗЕМНИХ МОВ
}

Анотація. Значна роль у професійній підготовці майбутніх учителів іноземним мов відводиться іншомовній компетентності. Однією з складових іншомовної компетентності $є$ фонетична. Фонетична компетентність присвячена вивченню мовних одиниць найнижчого рівня мовної структури - фонетикофонологічного. Значущість засвоєння фонетичного матеріалу зумовлюється тією роллю, яку виконують фонетичні одиниці в системі мови як засобу спілкування.

Актуальність дослідження фонетичних питань зумовлюється компетентнісним підходом, зорієнтованим на формування готовності майбутніх учителів іноземних мов до професійно-педагогічної діяльності, яка забезпечується сукупністю загальних, галузевих і спеціальних компетенцій. Метою статті $є$ дослідження особливостей фонетичної компетентності у майбутніх вчителів іноземних мов.

Проведено анкетування серед студентів I курсу. У ході анкетування було виокремлено особливості фонетичної компетентності: опанування студентами теоретичними знаннями про артикуляційно-акустичні властивості мовних звуків, закономірності їх сполучуваності у мовленнєвому потоці і пов'язані з ними функціональні зміни, роль звуків у формуванні, розпізнаванні і розрізнюванні значущих мовних одиниць вищих рівнів мовної структури - морфем, слів та їх форм, ознайомлення із процесами становлення звукової системи української мови протягом історичного періоду iї розвитку, з'ясування виникнення або занепаду звуків, еволюцію звукових явищ у розвитку фонетичної системи сучасної української мови. Отримані знання допомагають сформувати фонетичну усвідомленість майбутнього вчителя іноземної мови. Фонетична усвідомленість майбутнього вчителя іноземної мови передбачає процес опанування студентом опанування системи знань у галузі фонетики іноземної мови, усвідомлення переваг й недоліків власної фонетичної компетентності.

Зроблено висновок, фонетична компетентність потребує не аби якої уваги. Виокремлено те, що необхідно робити акцент на індивідуальних особливостях сприйняття студентів, мовців, слухачів (адже, лексична одиниця може сприйматись по різному і для кожного мати свій контекст). Описано методику використання вправ для опанування фонетичною компетентністю. 
Ключові слова: компетентність, іншомовна компетентність, фонетична компетентність, комунікативні вправи, вправи на відтворення.

Diachok Nadiia Valentynivna Candidate of Pedagogical Sciences, Senior lecturer, Department of English Philology and Translation, Borys Hrinchenko University of Kyiv, Bulvarno-Kudryavska St., 18/2, Kyiv, 04053, tel .: (044) 272-1902, e-mail: n.diachok@kubg.edu.ua, https://orcid.org/0000-0003-1355-6801

\title{
FEATURES OF PHONETIC COMPETENCE IN THE TRAINING OF THE FUTURE FOREIGN LANGUAGES TEACHERS
}

\begin{abstract}
A significant role in the training of future teachers of foreign languages is given to foreign language competence. One of the components of foreign language competence is phonetic. Phonetic competence is devoted to the study of language units of the lowest level of language structure - phonetic-phonological. The importance of learning phonetic material is due to the role played by phonetic units in the language system as a means of communication.
\end{abstract}

The relevance of the study of phonetic issues is due to the competency approach, focused on the formation of the readiness of future foreign language teachers for professional and pedagogical activities, which is provided by a set of general, sectoral and special competencies. The aim of the article is to study the features of phonetic competence in future foreign language teachers.

A survey was conducted among first-year students. In the course of the questionnaire the peculiarities of phonetic competence were singled out: students mastering theoretical knowledge about articulatory-acoustic properties of speech sounds, regularities of their compatibility in speech flow and related functional changes, role of sounds in formation, recognition and distinction of significant language units of higher levels. structures - morphemes, words and their forms, acquaintance with the processes of formation of the sound system of the Ukrainian language during the historical period of its development, elucidation of the origin or decline of sounds, evolution of sound phenomena in the development of the phonetic system of modern Ukrainian. The acquired knowledge helps to form the phonetic awareness of the future foreign language teacher. Phonetic awareness of the future teacher of a foreign language involves the process of mastering by the student mastering the system of knowledge in the field of phonetics of a foreign language, awareness of the advantages and disadvantages of their own phonetic competence.

It is concluded that phonetic competence needs some attention. It is emphasized that it is necessary to emphasize the individual characteristics of the perception of students, speakers, listeners (after all, the lexical unit can be perceived differently and for each to have its own context). The method of using exercises for mastering phonetic competence is described.

Keywords: competence, foreign language competence, phonetic competence, communicative exercises, reproduction exercises. 
Постановка проблеми. Сьогодні соціум розглядає фахове знання як умову економічного зростання. Здатність суспільства створювати щось нове, адаптовувати і навпаки, перетворювати знання у джерело прибутку (за теорією «людського капіталу») та вміння використовувати все це, має величезний вплив для підвищення якості життя громадян України. Характерною рисою будь-якої краї ниє економіка. Відповідно до нашого дослідження економічний зріст вимірюється збільшенням об'єму якісних знань.

Слід пам'ятати, що сьогодні людина живе і діє в рухливому середовищі, яке визначає рівень непередбачуваного напряму змін. Відповідно до таких умов майбутній учитель іноземних мов, має володіти рядом якостей, які виступають на перший план: креативність мислення і швидкість прийняття рішень, здібність до постійного самонавчання й уміння адаптуватися до нових умов як професійних, так і соціальних, уміння відстежувати і правильно оцінювати стан власної діяльності та навколишнього простору (сформована рефлексія). Належний рівень адаптивності при професійній діяльності у швидкозмінному середовищі характеризує професійно мобільного майбутнього вчителя іноземних мов, тобто фахівця, який здатний вирішувати різноманітні проблеми без особистіснонаукового дискомфорту.

Поряд із постійним підвищенням вимог до професійної компетенції вчителя іноземної мови, в цілому популярність педагогічних професій знижується. Відповідно до проведеного нами експериментального дослідження, зниження рівня популярності професії вчителя іноземної мови пов'язано 3 надзвичайно низькою оплатою праці молодого вчителя, це, в свою чергу, характеризує загальну тенденцію суспільства до нівелювання моральних цінностей і засад. Не дивлячись на це, кожній людині необхідне усвідомлення власного місця в цьому житті, розуміння того, що праця, яка виконується ними, є необхідним і приносить незаперечну користь суспільству.

Аналіз останніх досліджень i публікацій. Проблема професійної підготовки вчителів висвітлена у наукових доробках учених: Н. Дем'яненко, О. Дубасенюк, І. Зязюна, В. Лугового, Н. Ничкало, В. Майбороди, О. Пєхоти, Н. Протасової Л. Хоружої; філософські аспекти цього процесу обгрунтовують: В. Андрущенко, В. Бондаренко, В. Князєв, М. Михальченко, В. Скуратівський; психологічні: І. Бех, Л. Божович, В. Бочелюк, Ю. Власенко, С. Занюк, Г. Костюк, I. Кукуленко-Лук'янець, Р. Немов, Т. Яценко. Висвітленню окремих питань формування готовності педагогів до професійної діяльності присвятили дисертаційні роботи К. Баханов, І. Богданова, О. Волошенко, І. Гавриш, А. Линенко, О. Савченко та інші. Безпосередньо дослідженням професійної підготовки вчителів іноземних мов займаються: А. Береснєнв, О. Божок, М. Князян, О. Місечко, О. Русановна, Н. Сура, В. Хмельковська, О. Шмирко.

Фонетична компетентність та особливості їі формування були предметом дослідження багатьох науковців: Л. Стабурової, Л. Прокопової, Т. Вербицької, Н. Красовської, Ю. Головач, В. Перлової, В. Кочубей, А. Долини, А. Атарщикової та інших.

Проаналізувавши наукову літературу слід зазначити, що науковці 
виокремлюють специфічну особливість у професійній підготовці майбутніх вчителів іноземних мов це сформована у них філологічна компетентність. Результатом сформованої у вчителя іноземної мови здатності до комунікації, $\epsilon$ його безконфліктний шлях знаходити взаємопорозуміння та становить запоруку професійного росту вчителя. Філологічна компетентність визначається як вузькоспеціальна професійна компетентність, яку необхідно формувати у вчителя-мовника.

Мета статті - дослідження особливостей фонетичної компетентності у майбутніх вчителів іноземних мов.

Виклад основного матеріалу. Сьогодні, професія майбутніх учителів англійської мови вимагає ряд сформованих компетентностей, зокрема фонетичної. Фонетична компетентність $є$ обов'язковою складовою іншомовної компетентності майбутнього вчителя іноземної мови. Формування означеної компетентності забезпечують заклади вищої освіти.

Виокремимо основні особливості фонетичної компетентності майбутнього вчителя іноземної мови (див. рис. 1):

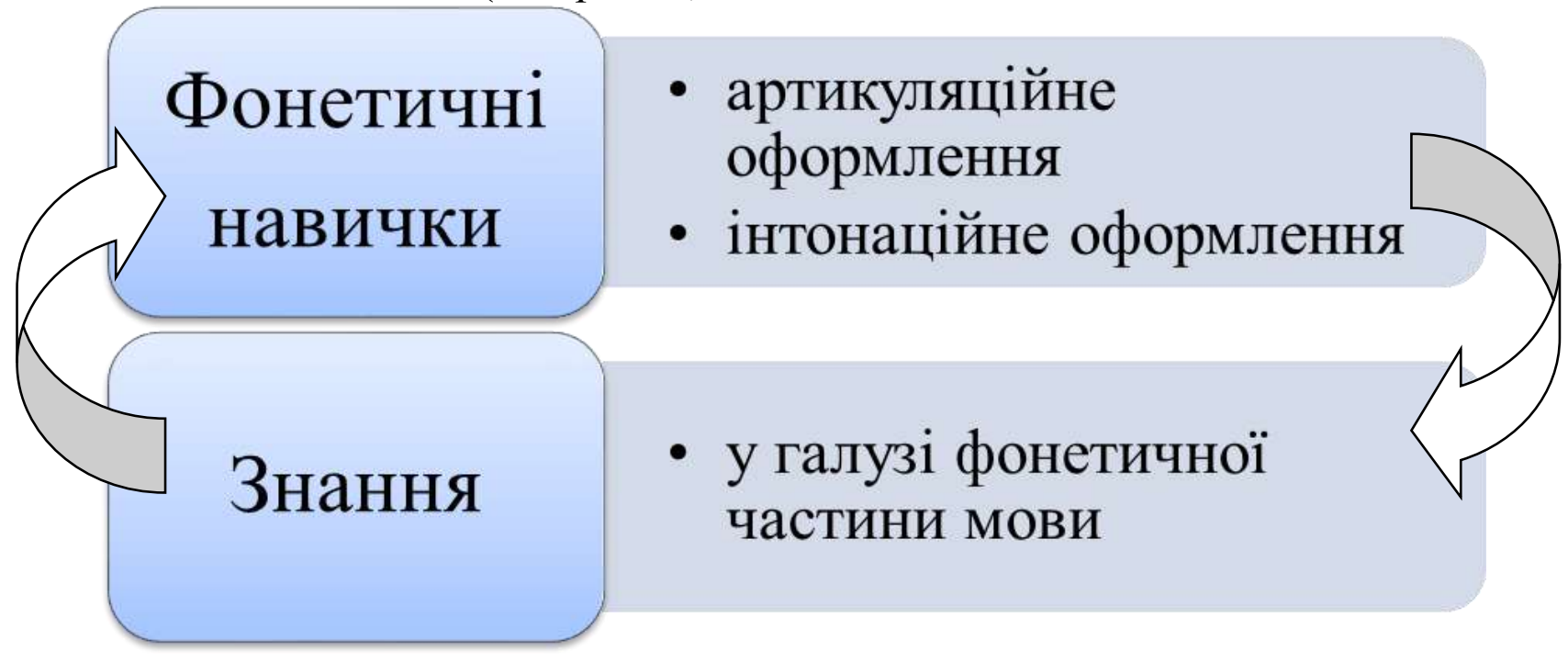

\section{Pис.1. Особливості фонетичної компетентності}

Джерело: розроблене автором

Фонетична компетентність майбутніх вчителів іноземних мов є системною дефініцію, яка включає сформовані вміння вірного артикуляційного та інтонаційного оформлення висловлювання i розуміння інших. Означена особливість можлива лише при наявності відповідних навичок, знань. Фонетична усвідомленість майбутнього вчителя іноземної мови залежить від рівня сформованості складових досліджуваної компетентності: фонетичних навичок, обсягу знань про фонетичну систему мови та динамічній взаємодії цих складових.

Сьогодні фонетична компетентність майбутнього вчителя іноземної мови розглядається як здатність людини до коректного звукового й інтонаційного забарвлення власної вимови і розуміння мовлення інших, яка грунтується на динамічній взаємодії усіх особливостей фонетичної компетентності [2, с. 192]. 
Наше дослідження потребувало проведення опитування серед студентів 1 курсу щодо розуміння і увідомлення майбутніми учителями іноземних мов необхідності фонетичної компетентності у їхній майбутній діяльності. вимагає визначення реального стану сформованості професійної мобільності майбутніх учителів іноземних мов в освітньому середовищі університеті. Анкетування пройшли 60 студентів I курсу Київського університету імені Бориса Грінченка.

Три основні питання, які ставилися студентам підчас анкетування:

1. Що таке фонетика англійської мови?

2. Які навички майбутньому вчителю іноземної мови забезпечує вивчення фонетики? мови?

3. Чи потрібна конкретна методика для вивчення фонетики англійської

Отримані результати дали змогу сформулювати попередні узагальнення.

Студенти не зовсім уявляють, що таке фонетика, іï особливостей та необхідність методики.

Статистичні дані першого опитування

\begin{tabular}{|c|c|c|c|}
\hline Питання & $\begin{array}{l}\text { Ст. } \\
\text { дані }\end{array}$ & Варанти відповідей & Ст. дані \\
\hline \multirow{5}{*}{ Оберіть складові фонетики } & \multirow{5}{*}{$32,6 \%$} & Інтонація & $9,8 \%$ \\
\hline & & Звуки & $12,6 \%$ \\
\hline & & Артикуляція & $5,9 \%$ \\
\hline & & Фонетичні процеси & $39,1 \%$ \\
\hline & & Всі вище перераховані елементи & $32,6 \%$ \\
\hline \multirow{7}{*}{$\begin{array}{l}\text { Оберіть навички та вміння, } \\
\text { які забезпечує вивчення } \\
\text { фонетики }\end{array}$} & \multirow{7}{*}{$16,6 \%$} & Фонетична рецептивна (слухова) & $18,6 \%$ \\
\hline & & Репродуктивна (вимовна) & $8,2 \%$ \\
\hline & & $\begin{array}{ll}\text { Інтонаційне } & \text { оформлення } \\
\text { власного мовлення }\end{array}$ & $16,8 \%$ \\
\hline & & $\begin{array}{l}\text { Адекватне сприйняття звукового } \\
\text { й інтонаційного оформлення } \\
\text { мовлення інших }\end{array}$ & $6,7 \%$ \\
\hline & & $\begin{array}{l}\text { Модифікація звуків } \text { у потоці } \\
\text { мовлення }\end{array}$ & $4,8 \%$ \\
\hline & & Фонетична організація слів & $28,3 \%$ \\
\hline & & Всі вище перераховані елементи & $16,6 \%$ \\
\hline \multirow{2}{*}{$\begin{array}{lrr}\text { Чи потрібна } & \text { конкретна } \\
\text { методика } & \text { для } & \text { вивчення } \\
\text { фонетики } & & \text { англійської } \\
\text { мови? } & & \\
\end{array}$} & \multirow[b]{2}{*}{$78,2 \%$} & Так & $78,2 \%$ \\
\hline & & $\mathrm{Hi}$ & $21,8 \%$ \\
\hline
\end{tabular}

Джерело: розроблено автором

Отримані статистичні дані дали змогу констатувати, що студенти не повноцінно усвідомлюють мету і завдання блоку навчальних фонетичних дисциплін, зокрема, якими навичками і вміннями, вони зможуть оволодіти: фонетичні рецептивні (слухові) й репродуктивні (вимовні) навички, коректне 
звукове й інтонаційне оформлення власного мовлення й адекватне сприйняття звукового й інтонаційного оформлення мовлення інших; фонетичні знання про фонетичну сторону мовлення (фонеми та їхні артикуляційно-акустичні характеристики), основні модифікації звуків у потоці мовлення, фонетичну організацію слів (склад, словесний наголос), інтонацію та їі складники (мелодику, ритм, паузу, наголос, темп, гучність, тембр), транскрипцію тощо.

Вивчення блоку фонетичних дисциплін формують фонетичну усвідомленість майбутнього вчителя іноземної мови. Вона передбачає процес опанування студентом фонетичної компетентності підчас удосконалення вимови, опанування системи знань у галузі фонетики англійської мови, усвідомлення переваг й недоліків стосовно формування фонетичної компетентності.

Виокремимо, що наявність рефлексії у цьому випадку є обов'язковою. Адже саме рефлексія надає змогу аналізувати фонетичну сторону власного мовлення й приймати рішення щодо наявності грубих відхилень від нормативної вимови, аналізувати їх причини, використовувати пропоновані викладачем ефективні шляхи їх усунення.

Зазначимо, сучасні методичні підходи до формування фонетичної компетентності: комунікативний, особистісно-діяльнісний, компетентнісний, рефлексивний i культурологічний підходи, які реалізуються шляхом використання різних технологій навчання. Водночас кожний підхід, 3 урахуванням його особливостей, передбачає найефективнішу для його реалізації технологію навчання англійської мови.

Виокремимо, що під час роботи зі студентами I курсу важливим $\epsilon$ застосування мультимедійних засобів при формуванні фонетичної компетентності. Мультимедійні засоби забезпечують можливість обирати темп та рівень завдань, покращують швидкість засвоєння граматичних конструкцій та накопичення словник нового запасу.

Також безцінними технічними перевагами цього процесу вважаємо можливість використання інтерактивних відео - та аудіороликів при навчанні усному мовленню. При цьому демонстрування схем, фото та малюнків за тематикою мовного спілкування є реалізацією принципу наочності, що дозволяє візуалізувати, зробити більш цікавими вправи для роз виткну вмінь і навичок говоріння. Застосування мультимедійних технологій дозволяє самостійно готувати міні-проекти за тематикою спілкування та презентувати їх.

Друге анкетування було проведене після вивчення однієї 3 фонетичних дисципліни. Результати другого зрізу (див. рис. 2) до демонструють значну динаміку в отриманих даних. 3 цього слідує, що формування фонетичної компетентності підчас підготовки майбутніх учителів іноземних мов у закладах вищої освіти полягає у тому, щоб закласти у довготривалу пам'ять студентів нормативний склад вимовних елементів i автоматизувати їх відбір i комбінування. 


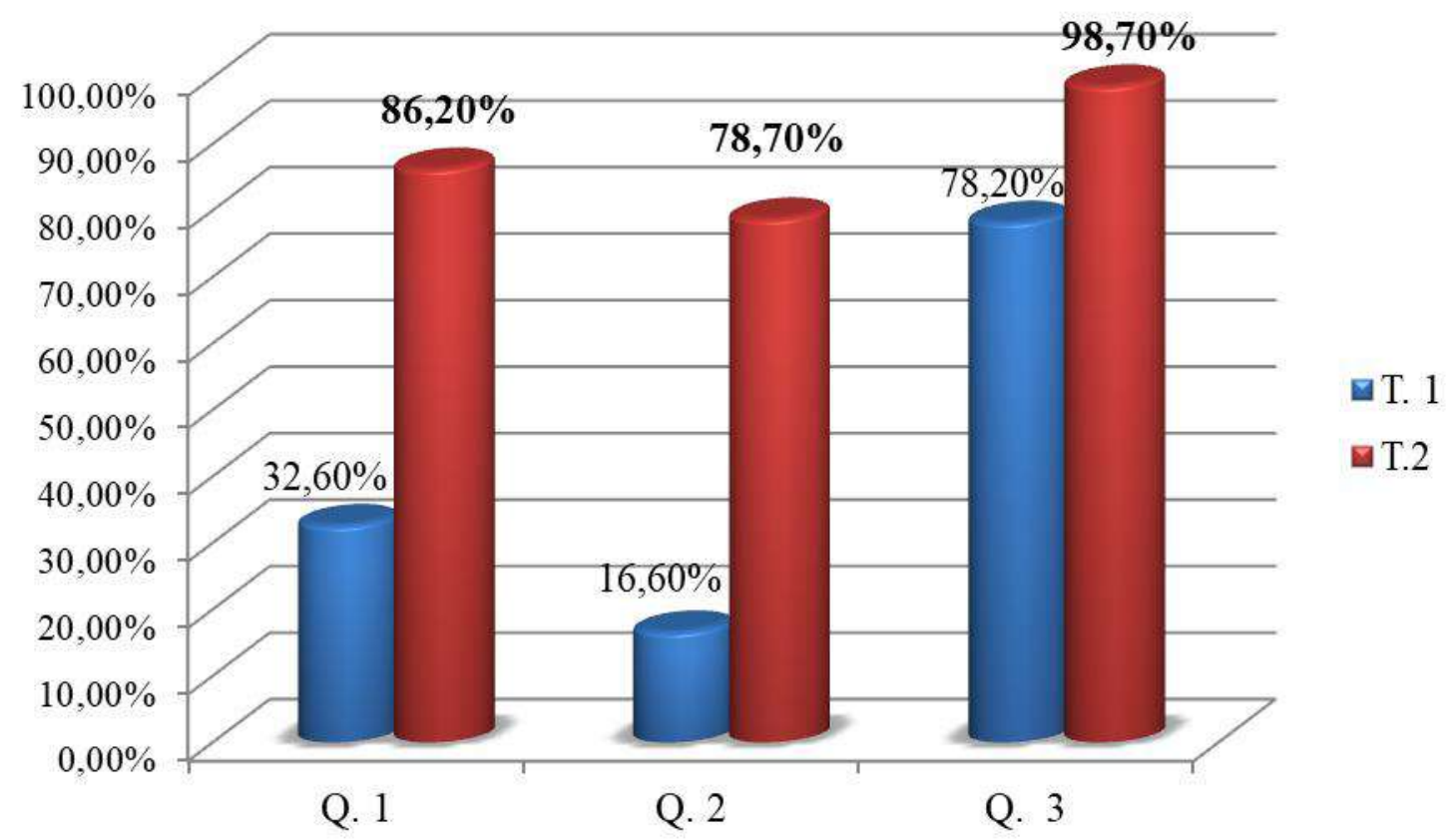

Pис. 2. Динаміка розуміння фонетичної складової студентами Джерело: розроблено автором

Досягнення цієї мети є можливим за умови застосування певної методики. Під означеною методикою маємо на увазі систему вправ, яка грунтується на різних особливостях, типах і видах вправ. Кожна вправа, незалежно від рівня іiі складності, включає обов'язкові компоненти: завдання до вправи, зразок виконання завдання і контроль виконання завдання [5].

Відповідно до методичного принципу, завдання фонетичної вправи повинно мати комунікативне спрямування. Однак слід зауважити, що у процесі формування фонетичної компетенції частина вправ на відтворення $\epsilon$ значною. фонетичні вправи на відтворення спрямовані на формування i розвиток фонематичного та інтонаційного слуху i, на жаль, не носять комунікаційне спрямування [3].

Наступним необхідним компонентом вправи для формування фонетичної компетенції є зразок виконання такої вправи. Вправи для розвитку фонетичного слуху повинні нести активний характер (концентрувати увагу студента на певній характеристиці фонеми чи фонетичного явища), а це стає можливим лише, коли студент виконує певні завдання, які спрямовані на аналіз явища.

Останнім компонентом $\epsilon$ вправи, які спрямовані на власну корекцію фонетичних помилок, ефективну самостійну роботу, а також корекцію у парній чи командній роботі.

Сьогодні оцінення оволодіння майбутніми учителями іноземних мов фонетичною компетентністю $є$ коректність артикуляційних та інтонаційних навичок.

Враховуючи вищезазначене, виокремимо основні структурні компоненти професійної компетентності викладача фонетики: соціально-педагогічна (наявність теоретико-методологічної, технологічної бази для проведення занять 3 фонетики та спеціально-дисциплінарних знань), організаційно-управлінська 
(наявність здатності до організації та управління освітньою діяльністю студентів підчас вивчення фонетики) та рефлексивно-комунікативна (вміння мотивувати до самоосвіти, самовдосконалення, допомогти адаптувати нову отриману інформацію до системи власних поглядів, власного життєвого досвіду того, хто навчається [4].

Висновок. Оволодіння фонетичною компетентністю $є$ необхідною умовою для здійснення ефективної іншомовної міжкультурної комунікації. Коректне фонетичне забарвлення мовлення майбутнього вчителя іноземної мови дає змогу йому не лише передавати інформацію, а й виражати власне ставлення до співрозмовника та предмета розмови, здійснювати вплив на учасників комунікативного процесу.

Фонетична компетентність є здатність майбутнього вчителя іноземної мови правильно артикулювати та інтонаційно висловлювати власні думки і розуміти мовлення інших. Для цього майбутнім учителям іноземних мов необхідно оволодіти відповідними фонетичними знаннями і навичками. Саме від їх рівня сформованості, від обсягу опанованого студентами знання та усвідомлення динамічної взаємодії цих компонентів залежить ефективність формування фонетичної компетентності майбутніх вчителів іноземної мови.

\section{Лimepamypa:}

1. Бориско Н. Ф. Методика формування іншомовної фонетичної компетентності / Н. Ф. Бориско // Методика навчання іноземних мов і культур: теорія та практика: підручник для студ. класичних, педагогічних і лінгвістичних університетів / під ред. С. Ю. Ніколаєвої. К .: Ленвіт, 2013. С . 195-215.

2. Гутник В.М. Особливості формування фонетичної усвідомленості у майбутніх вчителів у комунікативному вступному корективному курсі з німецької мови. Іноземні мови. 2016. №1. С. 24-30.

3. Дацьків О.П. Комплекс вправ для вдосконалення фонетичних навичок говоріння у майбутніх вчителів англійської мови засобами драматизації / О.П. Дацьків // Іноземні мови. 2014. №2. С. 34-38.

4. Котенко О. В. Сучасний викладач іноземної мови вищого навчального закладу: професійно-особистісний аспект. Вищза освіта України. 2012. № 3. С. 62-65

5. Ніколаєва С. Ю. Підходи до навчання іноземних мов і культур. Методика навчання іноземних мов і культур: теорія та практика: підручник для студ. класичних, педагогічних $\mathrm{i}$ лінгвістичних університетів / під ред. С. Ю. Ніколаєвої. К.: Ленвіт, 2013. С . 81-89.

6. Яценюк Н. I. Підготовка майбутнього вчителя іноземної мови до формування іншомовної комунікативної компетенції молодших школярів засобами підручника : змістовий компонент. 3б. наук. праць Київського національного університету імені Тараса Шевченка. Серія : педагогічні науки. 2011. № 6. С. 57-63.

\section{References:}

1. Borysko, N. F. (2013). Metodyka formuvannia inshomovnoi fonetychnoi kompetentnosti [Methods of forming foreign phonetic competence]. Metodyka navchannia inozemnykh mov i kultur: teoriia ta praktyka: pidruchnyk dlia stud. klasychnykh, pedahohichnykh i linhvistychnykh universytetiv - Methods of teaching foreign languages and cultures: theory and practice: a textbook for students. classical, pedagogical and linguistic universities, 195-215 [in Ukrainian]. 
2. Hutnyk, V. M. (2016). Osoblyvosti formuvannia fonetychnoi usvidomlenosti u maibutnikh vchyteliv u komunikatyvnomu vstupnomu korektyvnomu kursi z nimetskoi movy [Features of the formation of phonetic awareness in future teachers in the communicative introductory corrective course in German]. Inozemni movy - Foreign languages, №1, 24-30 [in Ukrainian].

3. Datskiv, O. P. (2014). Kompleks vprav dlia vdoskonalennia fonetychnykh navychok hovorinnia u maibutnikh vchyteliv anhliiskoi movy zasobamy dramatyzatsii [A set of exercises for improving phonetic speaking skills in future teachers of English by means of dramatization]. Inozemni movy - Foreign languages, №2, 34-38 [in Ukrainian].

4. Kotenko, O. V. (2012). Suchasnyi vykladach inozemnoi movy vyshchoho navchalnoho zakladu: profesiino-osobystisnyi aspekt [Modern foreign language teacher of higher education: professional and personal aspect]. Vyshcha osvita Ukrainy - Higher education in Ukraine, № 3, 6265 [in Ukrainian].

5. Nikolaieva, S. Yu. (2013). Pidkhody do navchannia inozemnykh mov i kultur [Approaches to teaching foreign languages and cultures]. Metodyka navchannia inozemnykh mov i kultur: teoriia ta praktyka: pidruchnyk dlia stud. klasychnykh, pedahohichnykh i linhvistychnykh universytetiv Methods of teaching foreign languages and cultures: theory and practice: a textbook for students. classical, pedagogical and linguistic universities, 2013, 81-89 [in Ukrainian].

6. Iatseniuk, N. I. (2011). Pidhotovka maibutnoho vchytelia inozemnoi movy do formuvannia inshomovnoi komunikatyvnoi kompetentsii molodshykh shkoliariv zasobamy pidruchnyka : zmistovyi komponent [Preparation of the future teacher of a foreign language for formation of foreign communicative competence of junior schoolboys by means of the textbook: semantic component]. Zb. nauk. prats Kyivskoho natsionalnoho universytetu imeni Tarasa Shevchenka. Seriia : pedahohichni nauky - Coll. Science. Proceedings of the Taras Shevchenko National University of Kyiv. Series: pedagogical sciences, № 6, 57-63 [in Ukrainian]. 